\title{
Seronegative Neuromyelitis Optica Spectrum - The challenges on disease definition and pathogenesis
}

\author{
O espectro da neuromielite optica seronegativa - os desafios na definição da doença e sua \\ patogênese
}

Douglas Kazutoshi Sato ${ }^{1,2}$, Dagoberto Callegaro², Marco Aurélio Lana-Peixoto³ , Ichiro Nakashima', Kazuo Fujihara ${ }^{4}$

\begin{abstract}
Neuromyelitis optica spectrum disorders (NMOSD) are characterized by severe optic neuritis and/or longitudinally extensive transverse myelitis, and some brain lesions are also unique to NMOSD. Serum autoantibodies against aquaporin-4 (AQP4) are detected in most cases of NMOSD. However, some patients with NMOSD remain seronegative despite repetitive testing during attacks with highly sensitive cellbased assays. The differential diagnosis of NMOSD is not restricted to multiple sclerosis and it includes many diseases that can produce longitudinally extensive myelitis and/or optic neuritis. We review the clinical features, imaging, and laboratory findings that can be helpful on the diagnostic work-up, discuss the differences between AQP4 antibody positive and negative patients with NMOSD, including features of NMOSD with antibodies against myelin oligodendrocyte glycoprotein.
\end{abstract}

Keywords: neuromyelitis optica, aquaporin-4, myelin oligodendrocyte glycoprotein, antibody, myelitis, optic neuritis, differential diagnosis.

RESUMO

O espectro da neuromielite óptica (NMOSD) é caracterizado por ataques graves de neurite óptica e mielite. Anticorpos séricos contra a aquaporina-4 (AQP4) são usualmente presentes nestes pacientes. Entretanto, alguns pacientes com NMOSD são seronegativos mesmo com testes repetidos em amostras obtidas durante ataques usando métodos altamente sensíveis baseados em células. 0 diagnóstico diferencial não é restrito à esclerose múltipla e inclui muitas doenças que podem produzir mielite longitudinalmente extensa e/ou neurite óptica. São abordadas as características clínicas, de imagem e de laboratório que podem ser úteis no diagnóstico, as diferenças entre os pacientes positivos para o anticorpo anti-AQP4 e os negativos, incluindo as características dos pacientes com NMOSD que possuem anticorpos contra a glicoproteína associada ao oligodendrócito.

Palavras-chave: neuromielite óptica, aquaporina-4, glicoproteína associada ao olidendrócito, mielite, neurite óptica, diagnóstico diferencial.

Neuromyelitis optica (NMO) and its limited forms known as NMO spectrum disorders (NMOSD) are characterized by severe optic neuritis (ON) and/or longitudinally extensive transverse myelitis ${ }^{1}$, and some brain lesions are also unique to NMOSD. Historically, Giovanni Battista Pescetto reported the first description suggestive of NMO in $1844^{2}$, but it was only in 1894 that Eugène Devic and his student Fernand Gault first used the term neuromyelitis optica (neuromyélite optique $)^{3}$. Interestingly, more than half of the patients from Lyon were males, $82.4 \%(14 / 17)$ of the cases were monophasic (i.e. simultaneous $\mathrm{ON}$ and myelitis), $88.2 \%$ $(15 / 17)$ had bilateral ON and $29.4 \%$ (5/17) had brain or brainstem symptoms ${ }^{4,5}$. Currently, the diagnosis of NMOSD is usually suspected in patients with the following phenotypes: monophasic or recurrent NMO, monophasic or recurrent longitudinally extensive transverse myelitis (LETM) that extends over three or more vertebral segments, and bilateral simultaneous or recurrent $\mathrm{ON}^{6}$. Although many patients

${ }^{1}$ Department of Neurology, Tohoku University School of Medicine, Sendai, Japan;

${ }^{2}$ Departamento de Neurologia, Faculdade de Medicina, Universidade de São Paulo, Sao Paulo SP, Brazil;

${ }^{3}$ Centro de Investigação em Esclerose Múltipla, Faculdade de Medicina, Universidade Federal de Minas Gerais, Belo Horizonte MG, Brazil;

${ }^{4}$ Department of Multiple Sclerosis Therapeutics, Tohoku University Graduate School of Medicine, Sendai, Japan. On behalf of Brazilian Committee for

Treatment and Research in Multiple Sclerosis (BCTRIMS).

Correspondence: Douglas Kazutoshi Sato; Seiryomachi Aobaku; 980-8574 Sendai, Miyagi, Japan; E-mail: douglas.sato@med.tohoku.ac.jp

Conflict of interest: There is no conflict of interest to declare.

Received 27 February 2014; Accepted 19 March 2014. 
have no lesions outside the optic nerve and spinal cord, several reports confirmed that NMOSD patients might also have some characteristic brain or brainstem lesions for $\mathrm{NMO}^{7,8,9,10}$, resulting in proposed diagnostic criteria that includes more features now considered typical for NMOSD ${ }^{11}$.

Serum antibodies against aquaporin-4 (AQP4) are present in the majority of NMOSD patients and its discovery clearly segregated NMOSD from multiple sclerosis (MS) ${ }^{12}$. More recently, we have reported patients with AQP4 antibodies that do not fulfill the current criteria for $\mathrm{NMOSD}^{13}$, such as monophasic unilateral ON with poor recovery, recurrent short myelitis, and recurrent attacks restricted to brainstem, indicating that a broaden disease definition associated with the AQP4 antibody as a biomarker may be warranted. The primary target for these autoantibodies is the AQP4, a bidirectional transmembrane water channel richly expressed in the endfeet of astrocytes ${ }^{14}$. These pathogenic IgG1 subclass antibodies against AQP4 are able to promote efficient antibody- and complement-dependent cell-mediated cytotoxicity causing severe astrocyte injury demonstrated on in-vitro, animal and human pathological studies ${ }^{15,16,17,18,19}$.

Cell-based assays with human AQP4 transfected living cells ${ }^{13,20,21}$ have higher sensitivity than the original mouse brain tissue-based immunofluorescence assay ${ }^{12}$ and the commercial ELISA. However, some of those patients remain seronegative, despite the use of the most sensitive assay currently available. Here, we review other diagnoses that can mimic NMOSD, the influence of AQP4 antibody assays on the seronegative group, the differences on the clinical phenotypes between AQP4 antibody seropositive and seronegative cases, and the presence of other antibodies in AQP4 antibody seronegative NMOSD patients.

\section{THE DIFFERENTIAL DIAGNOSIS OF NMOSD}

The first, and probably, the most frequent effort on the daily practice of neurologists is to differentiate NMOSD from $\mathrm{MS}^{22}$. Usually, NMOSD patients have more frequently a nonCaucasian ancestry, and an average age at onset higher than MS patients. NMO attacks are more severe and despite the efforts to treat aggressively the NMO attacks, many patients are left with permanent visual or motor incapacity ${ }^{1,23}$. Persistent (duration $>48$ hours) or intractable nausea, vomiting and hiccups are found in about $30 \%$ of NMOSD patients due to brainstem attacks ${ }^{8}$ and these symptoms are not reported at all in MS. Bilateral hypothalamic lesions seems also to be something only found in NMOSD patients, and these lesions may cause sleep disturbances such as narcolepsy and may be associated with low hypocretin levels in the cerebrospinal fluid $\left(\mathrm{CSF}^{24}\right)$. Painful tonic spasms during myelitis recovery and severe pain are found in NMOSD more commonly than in $\mathrm{MS}^{25,26}$. Neuropathic pruritus (itch) has also been recently reported in NMOSD patients during myelitis attacks ${ }^{27}$. Secondary progression without evidence of attacks suggestive of chronic progressive myelopathy is sometimes observed in MS, but it is not a common evolution seen on NMOSD ${ }^{1,28}$.

The brain MRI from NMOSD patients is normal, or have some abnormalities in areas with high-expression of AQP4 that usually do not fulfill the criteria for $\mathrm{MS}^{29,30,31}$. Less common brain lesions include large, edematous white matter lesions ${ }^{9}$ that may resemble posterior reversible encephalopathy syndrome ${ }^{32}$. Therefore, a careful evaluation of brain MRI lesions may be helpful to differentiate NMOSD from MS ${ }^{33,34}$. Brainstem lesions on the MRI associated with hiccups, nausea and vomiting are highly suggestive of $\mathrm{NMO}^{35}$, and these lesions may be present restricted to the brainstem or extend to the upper cervical spinal cord. The spinal cord MRI commonly shows LETM with three or more vertebral segments on the sagittal T2 MRI (sometimes with T1 contrastenhancement), and affects the central portion or the gray matter of the spinal cord ${ }^{36}$. In the chronic stage, the spinal cord T2 lesion may become fragmented on the MRI, and the spinal cord may show a severe atrophy.

The CSF analysis from NMOSD patients during attacks commonly shows a higher pleocytosis $\left(>50\right.$ cells $\left./ \mathrm{mm}^{3}\right)$ with presence of polymorphonuclear cells ${ }^{1}$, and lower frequency of oligoclonal IgG bands despite of the use of isoeletric focusing techniques ${ }^{37}$ compared to CSF from MS patients. NMOSD patients in acute exacerbations also have very high levels of glial fibrillary acidic protein (GFAP) in the CSF, accompanied by some elevation of S100B, and these levels correlate with the amount of functional disability and extension of the myelitis attacks ${ }^{38}$. GFAP levels in the CSF are quickly reduced after intravenous methylprednisolone. In contrast, elevated CSF levels of myelin basic protein and neurofilament $\mathrm{H}$ are much less prominent in NMO. All together, the CSF findings suggest that astrocytes are severely injured during NMOSD attacks and this is more pronounced than demyelination or axonal injury.

Another CSF finding in NMOSD is the elevation of interleukin-6 (IL-6), along with IL-1, IL-8, IL-13, and granulocyte colony-stimulating factor ${ }^{39}$. The IL-6 is a pro-inflammatory cytokine with pleiotropic effects and many cells, including astrocytes, can produce it. IL-6 can activate the signal transducer and activator of transcription 3 (STAT3), promoting the production of GFAP. The IL- 6 elevation in the CSF correlates well with GFAP levels, suggesting that activated or injured astrocytes are an important source of this cytokine. Moreover, IL-6 is relevant to the proliferation of B-cells, including a subset of differentiated B cells called plasmablasts $\left(\mathrm{CD} 19^{+} \mathrm{CD} 27^{\text {thigh }} \mathrm{CD} 38^{\text {thigh }}\right.$ cells) that are capable to produce AQP4 antibodies ${ }^{40}$. IL-6 is also important to induce polarization of CD4 T cells to Th17 cells. Therefore, pathogenic Th17 cells may also be stimulated by this increase of 
IL-6 levels ${ }^{41}$, and these cells may cross and disrupt the bloodbrain barrier ${ }^{42}$. More recently, a few case reports ${ }^{43,44}$ have recently described the experience with a monoclonal antibody against IL-6 receptor called tocilizumab with promising short-term results, suggesting that IL-6 pathway may be relevant to NMOSD pathogenesis.

The current awareness of NMOSD among neurologists is probably promoting the proper diagnosis of many patients during the first attack with confirmation of AQP4 antibody seropositivity. Unfortunately, some patients may be submitted to invasive procedures such as brain or spinal cord biopsies prior to AQP4 antibody testing to exclude tumors ${ }^{45}$. Pathological analysis of those biopsied specimens may reveal features compatible with NMOSD. Therefore, the careful evaluation of suspected NMO cases needs to be combined with high-sensitive assays for AQP4 antibody testing, even if not all clinical, MRI and laboratorial findings are not present in individual patients. NMOSD patients with myelitis usually present acute attacks with severe paraparesis or tetraparesis, sensory-level, and/or sphincter disturbances associated with LETM, which is already included as a supportive criterion in the Wingerchuk's 2006 diagnostic criteria for definitive $\mathrm{NMO}^{46}$. Severe $\mathrm{ON}$, sometimes bilateral with poor recovery and with altitudinal hemianopsia is observed in NMOSD $^{47}$. However, it is very important to emphasize that some patients that develop ON or LETM whose are seronegative for AQP4 antibodies may have other etiologies such as inflammatory (including acute disseminated encephalomyelitis), vascular, infectious, and paraneoplasic, diseases ${ }^{48}$.

\section{ILLUSTRATIVE CASES THAT MAY MIMIC SOME FEATURES FROM NMOSD PATIENTS}

We would like to illustrate the presence of NMOSD-like lesions in two cases that have LETM from our own experience that had other etiologies causing such lesions.

\section{Case 1}

The first case was a 69-years male with paraparesis developed with stepwise worsening over a 6-month period. The brain MRI was normal and the spinal cord MRI showed a LETM extending from T2 to T12 (Figure 1A) with homogeneous contrast enhancement (Figure 1B). AQP4 antibody and other autoantibodies were negative. CSF had no cells and only a slight increase on protein levels $(69 \mathrm{mg} / \mathrm{dl}$; reference $<40$ ) without elevation of IgG index. The subacute clinical course through months, the lack of evidence for inflammation or autoimmunity, and the contrast-enhancing pattern seen on the MRI did not support the diagnosis of NMOSD in this case. Later in the diagnostic work up, a spinal dural arteriovenous fistula was identified on the thoracic cord (Figure 1C).

\section{Case 2}

The second case was a 63-years old female that developed an acute transverse myelitis and nausea/vomiting episodes associated with fever 5 days before admission. The initial computerized tomography from spinal cord and brain were normal, but the spinal cord MRI showed a cervical LETM extending to the brainstem, with edema and central contrast enhancement (Figures 2A and 2B). She had at admission an elevated C-reactive protein level $(=31 \mathrm{mg} / \mathrm{dl}$; reference $<0.2$ ), and a high-white blood cell counts $(=24,900$ cells $/ \mu$; reference $<9,600)$ suggesting an inflammatory or infectious etiology. The CSF had 309 cells/ $\mu \mathrm{L}$ (reference <3) with 277 polymorphonuclear cells, elevated protein $(402 \mathrm{mg} / \mathrm{dL}$; reference $<40)$, low glucose $(2 \mathrm{mg} / \mathrm{dl}$; serum=180 mg/dl) and elevated LDH (1379 U/l; normal $<25$ ). The echocardiogram was normal, but the brain MRI showed hyperintense spotted lesions on the diffusion weighted imaging suggestive of multiple small brain embolism. Some days later, the CSF and blood culture were positive for S. pneumoniae, confirming the infectious origin of the myelitis. The patient responded well to antibiotics.

\section{THE DIFFERENCES BETWEEN AQP4 ANTIBODY POSITIVE AND NEGATIVE NMOSD PATIENTS}

The studies from France, German and Finland that compared the clinical characteristics of AQP4 antibody seropositive and seronegative patients with definite NMO showed that the seronegative ones have no female preponderance, a higher proportion of Caucasian ethnicity, monophasic disease, simultaneous optic neuritis and myelitis at onset and less severe visual impairment ${ }^{21,49,50,51}$. However, Marignier et al. ${ }^{21}$ showed that the some differences could only be demonstrated using highly sensitive AQP4 antibody assay using M23 isoform transfected cells, so it is clear that assays used in each study can directly influence the definition of the 'seronegative' group. We also share the experience from the French group, as about 20\% (15/72) patients positive for AQP4 antibodies by CBA using M23 isoform transfected living HEK-293 cells in our study were negative using the commercially based ELISA, and this seems to occur more frequently in patients with low-titers ${ }^{13}$. More recently, the Mayo group also published their experience using various commercial and in-house assays and they found that twothirds of the 49 NMO cases previously 'seronegative' were positive using more sensitive assays ${ }^{52}$.

In experimental studies, purified immunoglobulin G (IgG) from AQP4 antibody seronegative patients did not reproduce NMO-like pathology with astrocytic destruction as seen with the infusion of same material from AQP4 antibody seropositive patients ${ }^{17}$. Therefore, it is unclear 


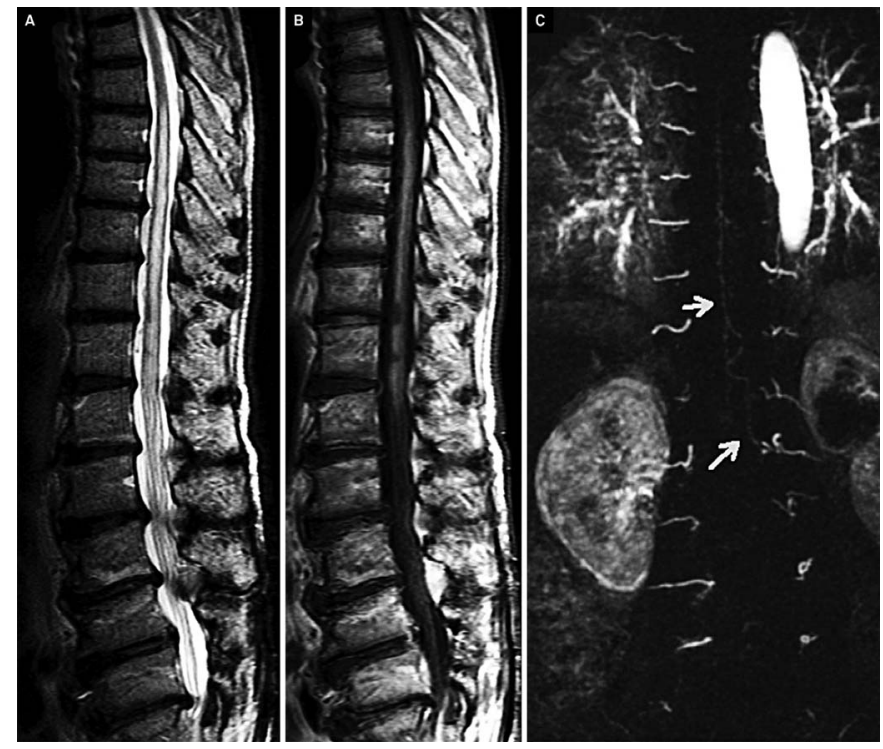

Figure 1. MRI T2-weighted sagittal, high-intensity lesion of the spinal cord extending over Th2-Th12 (Figure 1A) with homogeneous contrast enhancement (Figure 1B - T1 with gadolinium) in a patient with a spinal dural arteriovenous fistula on the thoracic cord (Figure 1C).

if AQP4 antibody seronegative NMO patients have the same autoimmune astrocytopathic disease as seropositive patients ${ }^{51,53}$.

\section{THE PRESENCE OF MOG ANTIBODIES ON AQP4 ANTIBODY SERONEGATIVE NMOSD}

Most patients with NMOSD are positive for AQP4 antibodies. However, about $10-50 \%$ of those patients are still negative for AQP4 antibodies despite the use of the most sensitive assays currently available. The patients without AQP4 antibodies (='seronegative' NMO) may be a heterogeneous group, and a subgroup of patients may be associated with other autoantibodies. Two studies reported patients with NMOSD phenotype with autoantibodies against myelin oligodendrocyte glycoprotein (MOG) using cell-based assays $^{54,55}$. More recently, we have investigated the positivity of MOG antibodies in a cohort of 215 NMOSD patients from Japan and Brazil. Among the AQP4 antibody seronegative patients, 16/76 (21.0\%) were positive for MOG antibodies. One patient had definitive NMO, 5 had monophasic or recurrent LETM, and 10 patients had bilateral simultaneous or recurrent ON. In this group of patients with MOG antibodies, female predominance was absent, patients with myelitis had lesions located in the lower thoracic cord to conus medullaris, and clinical recovery (visual or motor) of those patients was usually better than the patients with AQP4 antibodies $^{56}$. Another recent study from Oxford group comparing 9 patients positive to MOG antibodies and 20 patients with AQP4 antibodies replicated some of our findings in the MOG-antibody positive group such as lack of female predominance, good recovery after attacks, lower risk of visual and motor disability, and similar CSF findings ${ }^{57}$. They also found some gray matter lesions on the brain MRI as found in ADEM. Both studies suggested that these patients may have a spatially limited form of acute demyelinating encephalomyelitis and that some patients included in the original pathological study from Lyon $^{4}$ may actually have some similarities to these cases. Weinshenker and Wingerchuk ${ }^{58}$ hypothesized that those patients with MOG antibodies might explain a significant proportion of patients with a monophasic NMOSD, while patients with AQP4 antibodies may represent the majority of the cases with relapsing course. Longitudinal prospective follow-up studies are required to evaluate the change of MOG antibody titers through the disease course and its relationship with treatment response and risk of relapses.

In our and Oxford studies, no patient was positive for both antibodies (MOG and AQP4 antibodies) using cellbased assays (CBA), suggesting that they might represent distinct disorders ending with a similar phenotype. However, another study using ELISA to evaluate the presence of MOG antibodies in patients with optic neuritis found some patients positive for both MOG and AQP4 antibodies, and their clinical features were similar from patients with AQP4 antibodies ${ }^{59}$. There is a possibility that ELISA using linearized MOG protein fragments (e.g. extracellular domain) may produce non-specific antibody binding ${ }^{60}$, indicating that MOG antibodies tested by ELISA may have some limitations to identify the patients with antibodies that recognize conformational epitopes. Additional studies are required to 

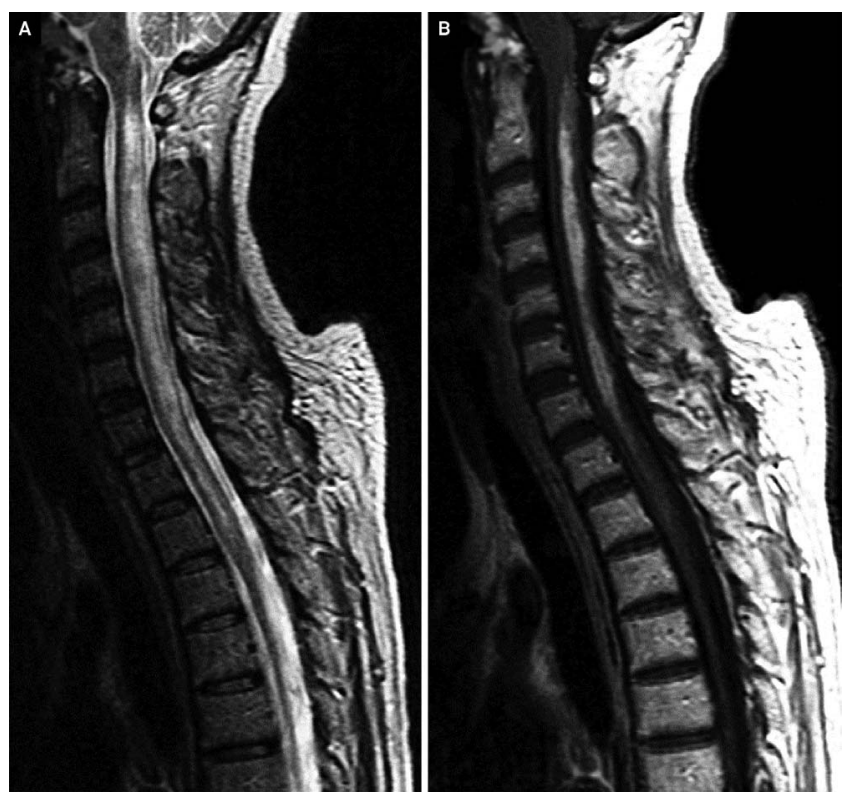

Figure 2

confirm the pathogenicity of those antibodies in experimental models, and investigate the clinical significance of MOG antibodies tested by different methodologies (e.g. CBA vs. ELISA).

\section{CONCLUSIONS AND FUTURE PERSPECTIVES}

The understanding of NMOSD has changed dramatically since the discovery of AQP4 antibodies. The positivity for AQP4 antibodies is not only a serum diagnostic marker, but also predicts a high-risk of further attacks, indicating the initiation of immunosuppressive therapy. The AQP4 antibody has been shown to be pathogenic in experimental studies (in vitro and in vivo), and pathological specimens from NMOSD patients with active lesions show severe astrocyte injury, and deposition of immunoglobulin and activated complement. The development of highly sensitive assays allowed the identification of clinical features that are distinct between AQP4 antibody seropositive and seronegative patients. Nevertheless, seronegative patients using those assays are still present, and they require careful investigation for other causes that can mimic NMOSD. MOG-antibodies have been recently identified in some AQP4 antibody seronegative patients, and they have some clinical features that suggest different underlying disease mechanisms from those patients with AQP4 antibodies (antibody mediated demyelination versus astrocyte injury). Further studies are required to clarify the underlying etiology in patients without detectable autoantibodies and determine whether they should be considered a distinct entity.

\section{References}

1. Wingerchuk DM, Hogancamp WF, O'Brien PC, Weinshenker BG. The clinical course of neuromyelitis optica (Devic's syndrome). Neurology 1999;53:1107-1114.

2. Jarius S, Wildemann B. The history of neuromyelitis optica. J Neuroinflammation 2013;10:8.

3. Devic E. Myelite subaiguë compliquée de névrite optique. Bull Med 1894;8:1033-1034.

4. Gault F. De la neuromyélite optique aiguë (Thèsis). Lyon, 1894.

5. Miyazawa I, Fujihara K, Itoyama Y. Neuromyelitis optica (Devic disease) and optic-spinal form multiple sclerosis. No To Shinkei (Brain and nerve) 2001;53:901-910.

6. Wingerchuk DM, Lennon VA, Lucchinetti CF, Pittock SJ, Weinshenker BG. The spectrum of neuromyelitis optica. Lancet Neurol 2007;6:805-815.

7. Pittock SJ, Lennon VA, Krecke K, Wingerchuk DM, Lucchinetti CF, Weinshenker BG. Brain abnormalities in neuromyelitis optica. Arch Neurol 2006;63:390-396.

8. Misu T, Fujihara K, Nakashima I, Sato S, Itoyama Y. Intractable hiccup and nausea with periaqueductal lesions in neuromyelitis optica. Neurology 2005;65:1479-1482.

9. Kim W, Park MS, Lee SH, et al. Characteristic brain magnetic resonance imaging abnormalities in central nervous system aquaporin-4 autoimmunity. Mult Scler 2010;16:1229-1236.

10. Sato D, Fujihara K. Atypical presentations of neuromyelitis optica. Arq Neuropsiquiatr 2011;69:824-828.

11. Lana-Peixoto MA, Callegaro D. The expanded spectrum of neuromyelitis optica: evidences for a new definition. Arq Neuropsiquiatr 2012;70:807-813.
12. Lennon VA, Wingerchuk DM, Kryzer TJ, et al. A serum autoantibody marker of neuromyelitis optica: distinction from multiple sclerosis. Lancet 2004;364:2106-2112.

13. Sato DK, Nakashima I, Takahashi T, et al. Aquaporin-4 antibodypositive cases beyond current diagnostic criteria for NMO spectrum disorders. Neurology 2013;80:2210-2216.

14. Lennon VA, Kryzer TJ, Pittock SJ, Verkman AS, Hinson SR. IgG marker of optic-spinal multiple sclerosis binds to the aquaporin-4 water channel. J Exp Med 2005;202:473-477.

15. Ratelade J, Asavapanumas N, Ritchie AM, Wemlinger S, Bennett JL, Verkman AS. Involvement of antibody-dependent cell-mediated cytotoxicity in inflammatory demyelination in a mouse model of neuromyelitis optica. Acta Neuropathol 2013;126:699-709.

16. Zhang $\mathrm{H}$, Bennett JL, Verkman AS. Ex vivo spinal cord slice model of neuromyelitis optica reveals novel immunopathogenic mechanisms. Ann Neurol 2011;70:943-954.

17. Bradl M, Misu T, Takahashi T, et al. Neuromyelitis optica: pathogenicity of patient immunoglobulin in vivo. Ann Neurol 2009;66:630-643.

18. Lucchinetti CF, Mandler RN, McGavern D, et al. A role for humoral mechanisms in the pathogenesis of Devic's neuromyelitis optica. Brain 2002;125:1450-1461.

19. Misu T, Fujihara K, Kakita A, et al. Loss of aquaporin 4 in lesions of neuromyelitis optica: distinction from multiple sclerosis. Brain 2007;130:1224-1234.

20. Waters PJ, McKeon A, Leite MI, et al. Serologic diagnosis of NMO: a multicenter comparison of aquaporin-4-IgG assays. Neurology 2012;78:665-671. 
21. Marignier R, Bernard-Valnet R, Giraudon P, et al. Aquaporin-4 antibody-negative neuromyelitis optica: Distinct assay sensitivitydependent entity. Neurology 2013;80:2194-2200.

22. Wingerchuk DM, Weinshenker BG. Acute Disseminated encephalomyelitis, transverse myelitis, and neuromyelitis optica. Continuum 2013;19:944-967.

23. Kitley J, Leite MI, Nakashima I, et al. Prognostic factors and disease course in aquaporin-4 antibody-positive patients with neuromyelitis optica spectrum disorder from the United Kingdom and Japan. Brain 2012;135:1834-1849.

24. Baba T, Nakashima I, Kanbayashi T, et al. Narcolepsy as an initial manifestation of neuromyelitis optica with anti-aquaporin-4 antibody. J Neurol 2009;256:287-288.

25. Kim SM, Go MJ, Sung JJ, Park KS, Lee KW. Painful tonic spasm in neuromyelitis optica: incidence, diagnostic utility, and clinical characteristics. Arch Neurol 2012;69:1026-1031.

26. Kanamori Y, Nakashima I, Takai Y, et al. Pain in neuromyelitis optica and its effect on quality of life: A cross-sectional study. Neurology 2011;77:652-658.

27. Elsone L, Townsend T, Mutch K, et al. Neuropathic pruritus (itch) in neuromyelitis optica. Mult Scler 2013;19:475-479.

28. Sato D, Fujihara K. Neuromyelitis optica without typical opticospinal phenotype. Mult Scler 2010;16:1154-1155.

29. Pittock SJ, Weinshenker BG, Lucchinetti CF, Wingerchuk DM, Corboy JR, Lennon VA. Neuromyelitis optica brain lesions localized at sites of high aquaporin 4 expression. Arch Neurol 2006;63:964-968.

30. Poppe AY, Lapierre Y, Melancon D, et al. Neuromyelitis optica with hypothalamic involvement. Mult Scler 2005;11:617-621.

31. Polman $\mathrm{CH}$, Reingold SC, Banwell B, et al. Diagnostic criteria for multiple sclerosis: 2010 revisions to the McDonald criteria. Ann Neurol 2011;69:292-302

32. Magana SM, Matiello M, Pittock SJ, et al. Posterior reversible encephalopathy syndrome in neuromyelitis optica spectrum disorders. Neurology 2009;72:712-717.

33. Huh SY, Min JH, Kim W, et al. The usefulness of brain MRI at onset in the differentiation of multiple sclerosis and seropositive neuromyelitis optica spectrum disorders. Mult Scler 2014;20:695-704.

34. Matthews L, Marasco R, Jenkinson M, et al. Distinction of seropositive NMO spectrum disorder and MS brain lesion distribution. Neurology 2013;80:1330-1337.

35. Takahashi T, Miyazawa I, Misu T, et al. Intractable hiccup and nausea in neuromyelitis optica with anti-aquaporin-4 antibody: a herald of acute exacerbations. I Neurol Neurosurg Psychiatry 2008;79:1075-1078.

36. Nakamura M, Miyazawa I, Fujihara K, et al. Preferential spinal central gray matter involvement in neuromyelitis optica. An MRI study. J Neurol 2008;255:163-170.

37. Nakashima I, Fujihara K, Sato S, Itoyama Y. Oligoclonal IgG bands in Japanese patients with multiple sclerosis. A comparative study between isoelectric focusing with IgG immunofixation and high-resolution agarose gel electrophoresis. J Neuroimmunol 2005;159:133-136.

38. Takano R, Misu T, Takahashi T, Sato S, Fujihara K, Itoyama Y. Astrocytic damage is far more severe than demyelination in NMO: a clinical CSF biomarker study. Neurology 2010;75:208-216.

39. Uzawa A, Mori M, Arai K, et al. Cytokine and chemokine profiles in neuromyelitis optica: significance of interleukin-6. Mult Scler 2010;16:1443-1452.

40. Chihara N, Aranami T, Sato W, et al. Interleukin 6 signaling promotes anti-aquaporin 4 autoantibody production from plasmablasts in neuromyelitis optica. Proc Natl Acad Sci U S A 2011;108:3701-3706.
41. Harris TJ, Grosso JF, Yen H-R, et al. Cutting edge: an in vivo requirement for STAT3 signaling in TH17 development and TH17dependent autoimmunity. J Immunol 2007;179:4313-4317.

42. Kebir H, Kreymborg K, Ifergan I, et al. Human TH17 lymphocytes promote blood-brain barrier disruption and central nervous system inflammation. Nat Med 2007:13:1173-1175.

43. Araki M, Aranami T, Matsuoka T, Nakamura M, Miyake S, Yamamura T. Clinical improvement in a patient with neuromyelitis optica following therapy with the anti-IL-6 receptor monoclonal antibody tocilizumab. Mod Rheumatol 2013;23:827-831.

44. Kieseier BC, Stuve O, Dehmel T, et al. Disease amelioration with tocilizumab in a treatment-resistant patient with neuromyelitis optica: implication for cellular immune responses. JAMA Neurol 2013;70:390-393.

45. Sato DK, Misu T, Rocha CF, et al. Aquaporin-4 antibody-positive myelitis initially biopsied for suspected spinal cord tumors: Diagnostic considerations. Mult Scler 2014;20:621-626.

46. Wingerchuk DM, Lennon VA, Pittock SJ, Lucchinetti CF, Weinshenker BG. Revised diagnostic criteria for neuromyelitis optica. Neurology 2006;66:1485-1489.

47. Nakajima H, Hosokawa T, Sugino M, et al. Visual field defects of optic neuritis in neuromyelitis optica compared with multiple sclerosis. BMC Neurol 2010;10:45.

48. Kitley J, Leite M, George J, Palace J. The differential diagnosis of longitudinally extensive transverse myelitis. Multiple Sclerosis Journal 2012;18:271-285.

49. Ketelslegers IA, Modderman PW, Vennegoor A, Killestein J, Hamann D, Hintzen RQ. Antibodies against aquaporin-4 in neuromyelitis optica: distinction between recurrent and monophasic patients. Mult Scler 2011;17:1527-1530.

50. Jarius S, Ruprecht K, Wildemann B, et al. Contrasting disease patterns in seropositive and seronegative neuromyelitis optica: a multicentre study of 175 patients. J Neuroinflammation 2012;9:14.

51. Fujihara K, Leite MI. Seronegative NMO: a sensitive AQP4 antibody test clarifies clinical features and next challenges. Neurology 2013;80:2176-2177.

52. Jiao Y, Fryer JP, Lennon VA, et al. Updated estimate of AQP4-IgG serostatus and disability outcome in neuromyelitis optica. Neurology 2013;81:1197-1204.

53. Fujihara K, Misu T, Nakashima I, et al. Neuromyelitis optica should be classified as an astrocytopathic disease rather than a demyelinating disease. Clin Exp Neuroimmunol 2012;3:58-73.

54. Mader S, Gredler V, Schanda K, et al. Complement activating antibodies to myelin oligodendrocyte glycoprotein in neuromyelitis optica and related disorders. J Neuroinflammation 2011;8:184.

55. Kitley J, Woodhall M, Waters P, et al. Myelin-oligodendrocyte glycoprotein antibodies in adults with a neuromyelitis optica phenotype. Neurology 2012;79:1273-1277.

56. Sato DK, Callegaro D, Lana-Peixoto MA, et al. Distinction between MOG antibody-positive and AQP4 antibody-positive NMO spectrum disorders. Neurology 2014;82:474-481.

57. Kitley J, Waters P, Woodhall M, et al. Neuromyelitis optica spectrum disorders with aquaporin-4 and myelin-oligodendrocyte glycoprotein antibodies. JAMA Neurol 2014;71:276-283.

58. Weinshenker BG, Wingerchuk DM. The two faces of neuromyelitis optica. Neurology 2014;82:466-467.

59. Kezuka T, Usui Y, Yamakawa N, et al. Relationship between NMOantibody and anti-MOG antibody in optic neuritis. J Neuroophthalmol 2012;32:107-110.

60. O'Connor KC, McLaughlin KA, De Jager PL, et al. Self-antigen tetramers discriminate between myelin autoantibodies to native or denatured protein. Nat Med 2007;13:211-217. 